Etnográfica

Revista do Centro em Rede de Investigação em

Antropologia

vol. $15(2) \mid 2011$

Vol. 15 (2)

\title{
Ramon Sarró, The Politics of Religious Change on The Upper Guinea Coast: Iconoclasm Done and Undone
}

\author{
J. D. Y. Peel
}

\section{OpenEdition}

\section{Journals}

Electronic version

URL: https://journals.openedition.org/etnografica/993

DOI: 10.4000/etnografica.993

ISSN: 2182-2891

\section{Publisher}

Centro em Rede de Investigação em Antropologia

\section{Printed version}

Date of publication: 1 June 2011

Number of pages: 395-399

ISSN: 0873-6561

\section{Electronic reference}

J. D. Y. Peel, "Ramon Sarró, The Politics of Religious Change on The Upper Guinea Coast: Iconoclasm Done and Undone", Etnográfica [Online], vol. 15 (2) | 2011, Online since 23 October 2011, connection on 12 February 2022. URL: http://journals.openedition.org/etnografica/993 ; DOI: https://doi.org/10.4000/ etnografica.993

Etnográfica is licensed under a Creative Commons Attribution-NonCommercial 4.0 International License. 
Ramon Sarró

\section{THE POLITICS OF RELIGIOUS CHANGE ON THE UPPER GUINEA COAST: ICONOCLASM DONE AND UNDONE}

Edinburgh, Edinburgh University Press, 2008, xvii + 238 pp.

Ramon Sarró's The Politics of Religious Change on the Upper Guinea Coast - which was originally meant to be known by its subtitle Iconoclasm Done and Undone - is No. 38 in the International African Library (IAL), the monograph series of the International African Institute (IAI). Its aim is to publish high-quality ethnography, and it is in the light of the changing requirements for ethnographic writing that I shall comment on Sarró’s book.

The IAI is the oldest continuous outlet for the publication of Africanist ethnography. Mostly it has worked through a university press, which for several decades was Oxford, then Manchester (1980-1989), then Edinburgh (1990-2009), and is now Cambridge. Its commitment to this role in this goes back to the 1930s, when alongside the publication of its flagship journal Africa, it began to publish the monographs produced by its research fellows. This programme of anthropological research, funded by the Rockefeller Foundation, was directed by Bronislaw Malinowski. Such classic ethnographies as Meyer Fortes's Web of Kinship among the Tallensi, followed by Dynamics of Clanship, and later Mary Douglas's The Lele of Kasai and John Middleton's Lugbara Religion came out under the OUP/IAI imprint. So too those enormously influential collections, African Political Systems (eds. Fortes and Evans-Pritchard) and African Systems of Kinship and Marriage (eds. Radcliffe-Brown and Forde), which did so much to define "British" social anthropology in its structural-functionalist heyday. Under the long directorship of Daryll Forde (1944-1973), the IAI's publishing programme expanded greatly, and a significant effort was made to encompass the very different tradition of French ethnographic writing. So a third collection, edited by Forde himself, African Worlds (1954), included essays by Mercier, Griaule and Dieterlen as well as by Douglas, Little and Lienhardt. And an ambitious project of ethnographic documentation, aimed to cover the whole Sub-Saharan area, The Ethnographic Survey of Africa, which ran between 1951 and the 1970s, had volumes in French as well as in English.

The IAI underwent a major reorganization of its activities from the late 1980s, partly in response to internal problems following the death of Daryll Forde, partly in response to the changed environment, both of Africa and of Africanist research. Central to this was a reappraisal of what ethnography should try to do. Since the 1960s, Africa had been joined by a bevy of other journals - some general, others specializing 
by region or discipline - and it was necessary to sharpen its distinctive profile. Regarded as an anthropological journal - though with a significant proportion of its contributors coming from other disciplines - Africa still had as its essential mission to provide an outlet for the publication of theoretically informed ethnography. Yet this could no longer be of the "classical" kind. In terms of subject-matter African ethnography needed to be extended into three main directions: to be more concerned with development, and with the relations between the local and the national, or society beyond the local community; to deal more with the interface between the social and the environmental; and to engage more profoundly with history, in both its objective and its subjective dimensions. ${ }^{1}$ When it was decided, in 1986, to launch the International African Library as a monograph series - the IAI's books having previously been published as isolated titles - the same brief was to apply, since the journal and the monograph series were envisaged as complementary to one another.

Ramon Sarró's book fits the rubric of the IAL in the fullest way, since it deals with the impact on the Baga of Guinea-wide religious and political forces, it connects their social and cultural forms with their specific river-dissected terroir, and it reflects profoundly on how that movement of 50 years ago has been absorbed into the ongoing history and the memories of Baga people today. Now "ethnography", famously, has a double reference: to the doing of the research, and to the manner of writing it, and Sarró's ethnography is thoroughly up-to-date, not just in its choice of subject-matter, but in how it is written. One important thing that distinguishes contemporary ethnographies at their best from such classic ones as, say,

I As set out in my Editorial, 1980, Africa, 50: 243-247.
Henri Junod's Life of a South African Tribe or R.S. Rattray's various works on Ashanti, is that they are doubly sensitive to time and history: (i) to the "lived-in-timeness" of their subjects' existence, and (ii) to the temporally specific context of their own ethnographic practice. Taken together, these imply a break from the static and objectivist assumptions of early ethnographers, who imagined themselves as being like complex recording machines of static social and cultural forms.

The ethnographer's acceptance of the historicity of what he does rendered the old way of writing ethnography - some sort of historical or regional background perhaps, followed by a tour around the various institutional areas of a people's society and culture, all treated synchronically - outmoded. It bequeathed a new problem: how to construct a story-line which does justice to both the synchronic and the diachronic, the analytical and the narrative, aspects of the matter. But perhaps it is better to move away from the dualism of synchrony/diachrony and adopt a Braudelian model which assumes that everything is in flux, but at different rates, which would give us different but concurrent chronicities: a nearly static one of ecology and environment, a slowly-moving one of cultural and social forms, a fast-moving one of histoire évènementielle. The solution Sarró adopts is a circular narrative, which begins in the present of his fieldwork experience - which is not, of course, that dubious expository fiction, the "ethnographic present" - then moves in a sort of Braudelian sequence towards a key historical moment, and then brings us forward and returns us to the present. Only now, in the light of the past that Sarró has recuperated, is the present explicable. Let me follow this sequence in more detail, chapter by chapter.

Ch. 1. - Sarró reflects on his own research experience of the Baga of coastal 
Guinea, putting the reader at once in medias res and "on the spot", by an account of himself walking with his friend Lamin around his native village. Lamin points to a cassava field which was once a sacred forest In a sense, the aim of the whole book is to explain how that came to be.

Ch. 2-3 - Here we have the slowest moving part of the narrative, an account of the local environment, with its coastal inlets and mangrove swamps, the rice agriculture they supported, and the patterns of Baga settlement and the social relations they developed in the course of their exploitation: in effect, the first two chronicities suggested by Braudel.

Ch. 4 - The pace of history now starts to speed up, with the imposition of French colonial rule, and the perennial problems of colonialism all over Africa, of how to establish viable territorial and administrative units, and to create effective chiefs and raise taxes. Christianity enters as part of all this. The narrative culminates with the sense of growing malaise - "the burden of being Baga" - which grows under colonialism, and the stage is set for the central episode of the book.

Ch. 5 - A Muslim preacher called Asekou Sayon, a Malinké from the interior, launches an iconoclastic movement that lasted less than a year, in 1956-57. His main local constituency was the young men who rejected the burden of Baga "custom" as linked to both elders' and colonial authority. The sacred groves were cut down and replaced with mosques and schools. But Asekou's movement also had another significance, as a revitalization movement which people hoped would "put an end to death". That is, it was an anti-sorcery movement like the many others, recurrent and perennial, that have occurred across Africa. But, coming in Guinea when it did, Asekou's movement was also a vehicle, in a locality that felt itself to be marginal, of the delocalizing and modernizing culture promoted by Guinea's radical nationalist leader Sekou Touré.

Ch. 6 - The foregoing account of events in 1956-57 has of course been a matter of historical reconstruction, and Asekou a figure of the past. But then the narrative takes a surprise twist, as Sarró was himself surprised during his fieldwork, when he discovered that Asekou was still alive. We are taken to meet him, old and all-but-forgotten, yesterday's man indeed but still living in Conakry, Guinea's capital. The historical irony is that his brand of Islam, because it shared so many features with the traditional practices he had attacked, soon found itself pushed aside as superstitious by the standards of the official blend of scientific socialism and rationalized Islam promoted by the Touré regime. But that dispensation did not survive the deepening crisis which overtook the Guinean state throughout the 1970s, and eventually swept the regime away in 1984.

Ch. 7-9 - The narrative moves forward into the "neo-liberal' era of the last quartercentury, which is marked by a new localism, and the undoing of much of Asekou's iconoclastic revolution. There is a revalorization of Baga tradition, involving the revival, even among young Muslims, of such un-Islamic practices as dancing and masquerades, blending with other such new expressions of communal identity as football and carnivals. Sarró concludes with reflections on the predicament of relatively marginal peoples like the Baga in a world of stronger ethnic neighbours, a weaker state and global pressures.

A very honest and attractive feature of the book is Sarró's candour about the difficulties of doing ethnography among a people like the Baga. Ethnographic research, like any other human activity, has its own particular time and place, but it is primarily grounded in the spatial realm, since that is 
directly perceptible and can be systematically related to other co-existent features of the society. Hence the mode of explanation of classical ethnography depended essentially on situational analysis. The problem is that this tended to ignore the unseen, the habitually unspoken, which is where the "past in the present" of memory is to be found. We might think of these memories as a "latency" - not in any quasi-analytic sense, as if they formed part of some kind of social unconscious - but rather in the sense of something held in reserve, not immediately relevant to the routine demands of social life that the ethnographer soon becomes aware of. Sarró's conversation with his friend Lamin, with which the book opens, immediately alerts us to the timesaturatedness of place and the time-awareness of the people who live there, even though these may not be obvious. Accessing them is particularly difficult where, as with the Baga, there is a cultural predisposition to secrecy. Since the ethnographer does not initially know what to ask, the answers often come serendipitously. Reflecting on his own position in trying to make sense of things, Sarró characterizes ethnography as the "art of being late", a nice way of indicating how much of what gives significance to the present has already taken place, but lies in the memories of people.

Such latent memories are especially relevant in the study of religion, which is such a vehicle of potential messages from the past to the present. Sarró's book is a major contribution to the study of African religious movements (whether Muslim or Christian), and he knows the literature on them very well. Now what Asekou Sayon's movement reminds me of more than any other is William Wadé Harris's Christian iconoclastic movement of 1913-15 along the Ivory and Gold Coasts (to which Sarró briefly refers). He mentions earlier Muslim iconoclastic movements in West Africa, and cites the well-known paper by De Craemer, Vansina and Fox on Central Africa, which argues that there was a recurrent pattern of movements of social purification and cultural revitalization. ${ }^{2}$ The implication for both areas is that the memory of prior movements is latent, even when things seem quiet and routine; and that this keeps open the possibility of recurrence when the situation calls for it. In fact Harris's movement, which seems so original in terms of West Africa's Christian history, may well have precursors in prior Muslim iconoclastic movements. ${ }^{3}$

This leads directly on to a final issue raised in Sarró's book, though it is not one he is concerned to address directly: the interplay between Christianity and Islam in Baga history. The "rise of Christianity" enters his story in Chapter 4 with the first arrival of Catholic missionaries in 1898. Then in Chapter 5 we have the "rise of Islam", with a quickening of Muslim conversion in the mid-colonial period. Yet Islam must have had some sort of presence well before then, as we've already heard of the activities of the Touré clan before World War I. Catholicism made an alliance with Baga custom against Islam and was so seen by the Baga. Yet Asekou Sayon's jihad, as a movement of youth against the "heaviness" of a custom exploited by the elders, was preceded by a Catholic Youth Movement, deploying dances which also challenged the elders. The opening up of a new space

2 W. de Craemer, J. Vansina and R.C. Fox, 1976, "Religious movements in Central Africa: a theoretical study", Comparative Studies in Society and History, 18: 458-475.

3 This cannot be proved or documented, but several feature's of Harris's self-presentation (his inspiration though the angel Gabriel, his wearing of a turban and white gown, etc.) suggest its possibility. See further discussion in David A. Shank, Prophet Harris: The "Black Elijah" of West Africa (Leiden, Brill, 1994: 117, 192). 
for local cultural assertion after the fall of Sékou Touré's regime, expressed in football and masquerades, gave fresh opportunities for the Catholics to put themselves at the centre of things. Overall, it is as if both the Muslims and the Christians, at different times, were able to make themselves the key vectors of the Baga story. Are we to see them as complementing or alternating with one another? When we read of a young man named René Amadou and of a Jean whose father is called Sékou, or of another young man who went to Conakry, converted from

Mike McGovern

\section{MAKING WAR IN CÔTE D'IVOIRE}

Chicago and London, The University of Chicago Press and Hurst Co., $2011, x x v+238$ pp.

As the reader may know, the war in Côte d'Ivoire has not yet happened. Departing from this Baudrillard-esque harbor, Mike McGovern sails off to describe the situation in Côte d'Ivoire between 2002, when a civil war was, to the eyes of most of us, imminent (indeed, many violent episodes followed between 2002 and 2004), and 2007, when elections were approaching again, in a country geographically divided in two regions: the "north" (mostly Muslim and Mandingo, with close cultural and historical links to Mali) and the "south" (more predominantly Christian, with historical and cultural links to Ghana to the east and southern Liberia to the west).

Because of this clear-cut division, many people thought that there was a "civil war" in Côte d'Ivoire of "Southerners" against 'Northerners', Christians against Muslims,
Islam to Pentecostalism and started a football team called Ancestral Village, while his stay-at-home brother remained Muslim and founded one called Harlem City, we have to feel that there is a complex interpenetration between the two faiths, working itself out as the Baga struggle to position themselves between the local, national and global forces which impact upon their lives.

\section{J.D. Y. Peel}

School of Oriental and African Studies, University of London, UK

"autochthons" (the coastal people) against "strangers" (the northern people, many of whom, including political leader Ouattara, were politically classified as "strangers" in the late 1990s owing to their genealogical links to Malian citizens). Those were no doubt elements in the conflict, but this was triggered by a much bigger set of conditions. And it was not really a "civil war" like the ones the world witnessed in neighboring Sierra Leone and Liberia. There was a lot of cruelty, with several thousand deaths but, against our fears, it never became a war remotely comparable to the neighboring ones.

Ironically, the book has taken a long time to be produced. "Ironically" because the delay has been paralleled by that of the elections, which only took place at the end of 2010 and produced today's alarming situation, with two people (President Gbagbo and Ouattara, his northern opponent) each claiming to be the winner, the former supported by the Constitutional Council (and by some African countries), and the latter by the international community, and West African neighbors in particular, who have 